\title{
Market orientation, innovation, and firm performance-an analysis of Albanian firms
}

\author{
Rezart Prifti ${ }^{*}$ (D) and Genc Alimehmeti
}

\author{
* Correspondence: \\ rezartprifti@feut.edu.al \\ Faculty of Economy, University of \\ Tirana, Rr. Arben Broci, Tirane, \\ Albania
}

\begin{abstract}
The purpose of this paper is to analyze the concept of market orientation as an outer source of innovation for organizations in the context of Albania. We investigate the market orientation relation with innovation and firm performance by analyzing a sample of 99 companies operating in Albania. The relationships and the impact of market orientation on innovation and performance is tested empirically through structural equation modeling techniques (SEM). The analysis confirms prior theoretical and empirical findings in developed economies, however, it gives way to some contextual interpretations. The implications of this study are considerable in academia and in managerial purposes. In academia, considering that there is no research in Albania on the topic of us being aware of, nevertheless, we identify the need for deeper and wider research, especially with bigger sample sizes, industryspecific, and across industries to grasp more about market reality. On managerial account, its relevance relies in the distinction of market orientation construct and the right division of components within the company, and the adequate approach toward intelligence generation, dissemination, and reaction on it by responding to market needs and competition with innovative products and services.
\end{abstract}

Keywords: Innovation, Market orientation, Intelligence generation, Intelligence dissemination, Performance

JEL classification: $\mathrm{O} 310$

\section{Background}

Economic development and innovation is a sine qua non symbiosis. Innovation in today's economies makes the basis of economic development (Léger and Swaminathan 2006) and a noteworthy effect on economic growth (Cameron 1996; Rosenberg 2004) especially when the transformation into knowledge economy makes learning one of the most relevant processes for economic development (Boekema et al. 2000). The Schumpeterian distinction between knowledge creation and innovation (Schumpeter 1934) or idea commercialization, conditions the analysis in context of the knowledge economy, especially when it comes to countries like Albania.

The specificity of the country comes due to its scarcity of resources and abilities to invest in whichever innovation driver. In an economy that requires knowledge to grow and develop, this distinction plays a substantial role. Capello and Lenzi (2014) find that knowledge and innovation are economic growth drivers with different spatial impact,

(c) The Author(s). 2017 Open Access This article is distributed under the terms of the Creative Commons Attribution 4.0 International License (http://creativecommons.org/licenses/by/4.0/), which permits unrestricted use, distribution, and reproduction in any medium, provided you give appropriate credit to the original author(s) and the source, provide a link to the Creative Commons license, and indicate if changes were made. 
implying that knowledge benefits in growth are more concentrated, while growth benefits from innovation (idea commercialization) tend to be more widespread.

In other words, growth from innovation is more pervasive than from knowledge creation, and what is most important is that the condition holds true whether a knowledge-based is as an underlying condition or not. Such conclusions are not important only for policy-making, but have important implications also on studying innovation at a firm level.

Innovation plays an important role in the difficult transition to a knowledge-based economy that Albania is experiencing. Despite this transition, companies tend to innovate, build, and sustain their competitive advantage in order to offer customers superior value. All these processes involve gathering and processing of information related to customers, competitors, and market, thus, to the concept of market orientation. Market orientation is a strategic posture of a company that obtains internal and external information and disseminates it throughout the company. Lewrick et al. (2011) see market orientation as a process of strategically gathering information and disseminating it throughout the firm. This entire process requires organizational commitment and coordination.

The main objective of this paper is to investigate the relationship between market orientation and innovation. Furthermore, it studies the aforementioned relationship in a developing economical context, such as Albania, which has not been widely studied as advanced economies have. In addition, it investigates the market orientation, innovation, and firm performance relation, the most walked through path of research related with the topic. Moreover, some country contextual implications are analyzed through industry and size dummy variables. Lastly, the innovative approach of this paper relies on the construct conceptualization. We treat market orientation components as a way of organizational learning flow of information and followed Škerlavaj et al. (2010) logic in the model setup.

The data were collected from PACINNO (code 1 STR/0003) survey, funded by Adriatic IPA Cross-border Cooperation Programme 2007-2013. The survey included 109 companies of which, after careful consideration, only 99 turned out to have full data and therefore valuable for the study. We use previously proved and existing operationalization of information acquisition, information dissemination, and responsiveness. We find a positive and significant relationship regarding market orientation-innovation and market orientation-firm performance. We find no significant relationship between size and innovation or size and performance. On the contrary, when controlling by sector (service or production) we find that service-providing firms are more innovative than production firms, while the industry per se, proves not to be a determinant of firm performance.

The paper is structured as follows: initially, we introduce the relevant literature on market orientation, innovation, and their relation. Afterwards, we define the model setup and methodology, and lastly, we discuss the results and limitations of the study. The findings have useful implications for scholars. As to the best of our knowledge, this is the first attempt to study the relation of market orientation, innovation, and firm performance in Albania. Furthermore, for practitioners, it helps to understand the proper degree of market orientation that guarantees companies the right benefits from innovation and it enhances performance. 


\section{Literature review}

\section{Market orientation definition}

The first validated and one of the most used market orientation measures is created by Narver and Slater (1990). They presented a model comprised by three components and a uni-dimensional structure, where market orientation was deemed as a concept close to marketing. They defined market orientation as a business culture affecting superior customer value creation through three components, such as customer orientation, competitor orientation, and inter-functional orientation. Criticism on their front comes from using culture to interpret their results despite not having any empirical measure for company culture. In addition, Lado et al. (1998) added the fact that distributors relevance, and the environment were not taken into consideration as stakeholders.

Jaworski and Kohli (1993) define market orientation as "organization-wide generation of market intelligence pertaining to current and future needs of customers, dissemination of intelligence horizontally and vertically within the organization and organization wide action or responsiveness to market intelligence". Their critique emphasizes that associating market orientation with marketing implementation, without a universally accepted definition of marketing, is hard to stand in theoretical grounds.

Other scholars (Rivera 1995; Gatignon and Xuereb 1997; Hunt and Lambe 2000) consider market orientation as a strategic notion, arguing that market orientation is a complementary contribution to strategy, and it is important to strategic orientation. This perspective considers the environment as a stakeholder in the market orientation operationalization. Moreover, it recognizes the strategic posture of the notion toward building a competitive advantage.

Narver and Slater (1990) emphasize the relation between competitive advantage and market orientation in order to create superior value for customers. They argue that more market orientation improves the analysis of sources of sustainable competitive advantage. The effective use of resources and capabilities results in competitive advantage for an organization (Lado et al. 1998), moreover, to sustain this advantage, companies need organizational knowledge that is not easily replicable by competitors. This kind of knowledge happens through the market orientation process and is innovation per se.

Market orientation definition can also be distinguished by the number of components that certain authors take into consideration. Narver and Slater (1990a) and Kohli et al. (1993) use three components (despite being different) with one-dimensional structures. Deng and Dart (1994) use four components with multi-dimensional and a multi factor structure. Lado et al. (1998) use eight components and Sorensen (2005) uses two constructs in a uni-dimensional structure. Another theoretical conundrum is the dualism of market orientation concept analysis, noticeable also from the aforementioned definitions. Approaches divide between one that considers market orientation as a company culture or the cultural perspective (Homburg and Pflesser 2000; Kirca et al. 2005) and one that treats market orientation as a certain set of behaviors, or the behavioral or process approach (Vázquez et al 2001a; Lado and Maydeu-Olivares 2001). Narver et al. (2004) make a distinction between two behavioral sets: responsive and proactive.

Despite components and dimensionality, the process of information acquisition, information dissemination, and responsiveness should affect changes within the 
organization that will also impact its innovativeness. Market oriented companies are better equipped and positioned in customer needs anticipation thereby in a better position to respond them with innovative products and services (Hurley and Hult, 1998). In addition to anticipation Vázquez et al. (2001a) argue that market orientation helps in fulfilling market needs with more excellence than competitors.

The main fundamental question in this perspective is: if businesses are not market oriented, then in what are they oriented to? Therefore, the term market orientation becomes more a description of the relationship among several components such as: customers (not only), competition, organization and firms output, or the description of their constant relationship while operating in the market. Despite the variety of components and dimensions of different constructs that can be found in extant literature, marketing does not seem to be the paradigm on which market orientation definition and analysis stands on. In other words, the lack of a universally accepted marketing definition makes it difficult for scholars to define market orientation on marketing grounds. Many scholars emphasize the role of competitive advantage and strategic posture. From this perspective, market orientation can be seen more as a strategic notion. Beside strategy determining market orientation, and this last determining firm's capabilities of creating a competitive advantage, the role of organizational learning and culture has also to be emphasized. Organizational learning and organizational culture are two critical vantage points that condition all market orientation processes (Deshpande and Webster 1989), from information acquisition to responsiveness (Jaworski and Kohli 1993, 1993). The effect does not depend on the number of constructs or questions, because whatever it is, it includes information generation, learning, and reacting on the gathered evidence.

\section{Defining innovation}

Organizations are facing continuous pressure from competition, therefore, they have to optimize their decision-making capabilities on such forces. To survive and thrive in hyper connected and competitive markets, organizations find innovation as the most feasible solution (Kim and Mauborgne 2005). If in developed economies the dilemma is whether knowledge or advanced knowledge, or marketing innovation or tech innovation; in countries with limited investing capabilities that dilemma turns into knowledge creation or innovation.

A wide and substantial definition of innovation is comprised by Crossan and Apaydin (2010) as the "production or adoption, assimilation, and exploitation of value added novelty in economic social spheres; renewal and enlargement of products, services, and markets; development of new methods of production, and establishment of new management systems. It is both a process and an outcome", or a new structure pertaining to organization members (Damanpour 1991).

Various opposing definitions can be identified depending on the typology or dimension on which innovation is analyzed. Innovation can be technical (product and service) or administrative (process) innovation (Škerlavaj et al. 2010; Gopalakrishnan and Damanpour 1997; Daft 1978a), radical versus incremental innovation is the main dichotomy in organizational innovation typology emerged early in literature (Ettlie et al. 1984), also product and process innovation (Abernathy and Utterback 1978). 
Hurley and Hult (1998) see innovation as an aspect of firm's culture and openness toward new ideas. They introduce in their model the capacity to innovate, which is defined as "the ability of the organization to adopt or implement new ideas, processes, or products successfully." Regarding the capacity to innovate, Lundvall (1985) argues that innovation comes from accumulated knowledge and experience and can be an incremental technical change or an upsurge in technical opportunities.

Overall innovativeness is the total of all innovation activities implemented or put in practice, including radical and incremental from all typologies (Utterback 1996; Garcia and Calantone 2002; Gatignon et al. 2002; Tidd et al. 2005).

\section{Market orientation and innovation}

One important debate in literature regarding market orientation and innovation is whether the former fosters the latter or rather causes incremental improvements in products coming from customer preferences modifications (Vázquez et al. 2001). Despite the debate going on for decades (Atuahene-Gima 1996), there is vast research confirming the positive relationship between market orientation and innovation (Baker and Sinkula 1999; Greenley 1995; Lewrick 2009; Zhou et al. 2005). Lado and Maydeu-Olivares (2001) also argue that adopting market orientation principles affects positively innovation activities, their magnitude, and effectiveness.

Extant literature also explores the relationship from the context of company maturity: startups and matured companies. Lewrick et al. (2011) find that in startup companies, the relationship between a strong competitors' orientation and an incremental innovation is positive. However, when the same relationship is put in the context of mature companies, it proves to be contra productive. Moreover, Lewrick et al. (2011) find that in mature organizations being more customer-oriented is positively related with radical innovation. Overall, it seems that authors give evidence to (2001) findings.

Market orientation is widely seen as a tool for an organization to build and to improve its competitive advantage (Narver and Slater 1990a; Kohli et al. 1993). Market orientation efforts combined with organizational capabilities, enhance performance (Luca and Atuahene-Gima 2007; Morgan and Vorhies 2009) or improve innovation (Lukas and Ferrell 2000). Tidd et al. (2005) relate innovation to organization abilities recognizing market opportunities and materializing commercial relationships. Information acquisition, dissemination, and its usage are involved in the innovation process, as a process of knowledge absorption and transforming it into action, therefore, learning orientation through such process is a significant antecedent of innovation (Garcia and Calantone 2002; Keskin 2006).

Improving competitive advantage and recognizing market opportunities requires intelligence generation from different market operators such as competitors, clients, and partners.

Market orientation requires complex organizational knowledge (Lado et al. 1998) in order for the intelligence generated to be disseminated and absorbed within the organization. Hurley and Hult (1998) deem innovativeness as an aspect of firm's culture and openness toward new ideas. They also introduce the capacity to innovate, which is defined as "the ability of the organization to adopt or implement new ideas, processes, or products successfully". Market orientation components adopted in this construct describe a structural flow of information acquisition, absorption, and reaction. Therefore, 
the better the intelligence generated from the organization (adoption of new ideas) the better the information to be disseminated (implementation of new ideas, processes, or products) and the better the responsiveness (qualified as successful).

Thereby, our first hypothesis: H1: assigning greater importance to intelligence generation (In Gen) leads to better intelligence dissemination (In Dissem). Organizations capacities limit market orientation information infusion, thus, innovativeness from the perspective of company's culture. Capacities here are embedded as absorptive capacities described by Cohen and Levinthal (1990). Firms with greater capacity have greater potential to innovate (Cohen and Levinthal 1990) and have greater potential to develop a competitive advantage (Hurley and Hult 1998). Disseminating accumulated intelligence has a prerequisite to be fulfilled. Lado et al. (1998) and Cohen and Levinthal (1990) argue that in order to disseminate intelligence and information, the organization needs first to absorb it, but the process depends on several factors which are not the scope of this paper. The construct of market orientation is dynamic and requires responsiveness on intelligence gathered and disseminated within the organization. Thereby, our second hypothesis: H2: assigning greater importance to intelligence dissemination (In Dissem) leads to more responsiveness (Res) on organizational basis. We assume that the informational path is as follows: intelligence generation leads to intelligence dissemination which in turn leads to responsiveness or reaction.

Another approach investigating the channel "market orientation-innovation-firm performance" sees market orientation facilitating innovativeness, then the second one positively affecting business performance (Han et al. 1998; Deshpande et al. 1993). Atuahene-Gima (1996) confirms only the first phase of the channel, finding a significant contribution of market orientation on innovation, and a weak relation with market success, measured as performance by sales and profit.

Moreover, authors deduce that while market orientation de jure is crucial to performance, de facto are organizational learning and absorptive capacities. Kline and Rosenberg (1986) interpreted the innovation process as a chain of changes not limited only to hardware update, but including market environment, knowledge, and the social dynamics of the organization. The transition to innovation is made by looking at market orientation through the organizational learning lenses and the behavioral change perspective, thereby, being equivalent to innovation or mediating the relationship between MO and innovation (Raj and Srivastava 2016). Market orientation from the stand point used in this paper, includes market knowledge and organizational collaboration in interconnection. Luca and Atuahene-Gima (2007) find that both affect product innovation.

The organizational innovation is affected by the degree to which an organization is market oriented, interacts with customers and competitors, learns through the same information and implements change. Thus, our third hypothesis relates directly the outcome of market orientation as a process to innovation. H3: better responsiveness (Res) has positive impact on technical and on administrative innovation. Based on extant literature on innovation, on the definitions mentioned above and on the innovation construct (Škerlavaj et al. 2010), we make a distinction between administrative and technical innovation. Therefore, we raise a sub-hypothesis regarding the relation of market orientation and innovation. H3a: Better responsiveness (Res) has a positive impact on technical innovation. 
Market orientation, innovation, and firm performance Extant literature has confirmed the positive relation between innovation and firm performance (Rosenbusch et al. 2011; Koellinger 2008; Vincent et al. 2004; Omri 2015; Calantone et al. 2002; Lado and Maydeu-Olivares 2001). Innovation effects on firm performance vary from innovation type (Gunday et al. 2011), whether it is a product, process, organizational, or marketing innovation. Its effects depend on firm performance and on type of industry.

Rosenbusch et al. (2011) argued that the innovation effect on firm performance depends also on firms' size, finding that newly and small firms show more evident effects on performance from innovation than bigger and well-established firms. To test the described theory relating innovation and performance, we raise the following hypothesis: H4: higher innovation in the company will have a positive relationship with company performance. In addition, we also test the effect that size and sector have on the relationship between innovation and performance. Lastly, based on the distinction of innovation as a process and innovation as an output, we assess a relationship which appears tautological. Despite this common perception, we test this assumption by using different constructs. Thereby, we raise the following hypothesis: H4a: the higher the innovation as a process in the company, the higher the innovation as an output.

Market orientation literature has constantly emphasized the positive role that it has on business performance (Jaworski and Kohli 1993; Kumar et al. 1998; Boekema et al. 2000; Kanagasabai 2008, Neil et al. 2009; Frösén et al. 2016), especially when performance is measured using judgmental measures (Jaworski and Kohli 1993). Building a competitive advantage derives from understanding the customer needs, competitor actions, and technical development. Such understanding is possible through commitment to learning and market orientation (Calantone et al. 2002). The reasoning behind is that organizations that better track customer needs and timely respond to them achieve better satisfaction, thus, perform better in the market. Consequently, we raise the following hypothesis: H5: better responsiveness (Res) has positive impact on firm's performance. The conceptual model is represented in Fig. 3.

\section{Results and discussion}

\section{Sample selection}

The focus of this paper is the analysis of the market orientation as a source of innovation. Considering the low level of growth and innovation of Albanian companies (Hashi and Krasniqi 2011), we used a pool of 870 companies marked as possibly innovative from the Albanian Institute of Statistics. Thereafter, we randomly extracted a sample of 109 companies which is representative of the initial pool with a confidence level at $95 \%$ and a margin of error $10 \%$. The sample was equally distributed between small, medium, and large companies and was well-balanced between production, service, and primary sector companies (see Figs. 1 and 2).

The companies were contacted by a team of researchers which assisted the compilation of the questionnaire during a face-to-face interview. This approach tried to ensure that the respondents had a clear understanding of each question and did not attempt to skip any. Nevertheless, 10 companies were excluded due to the lack of information on the questions used for the operationalization of the concepts, lowering the sample to a final number of 99 companies. 


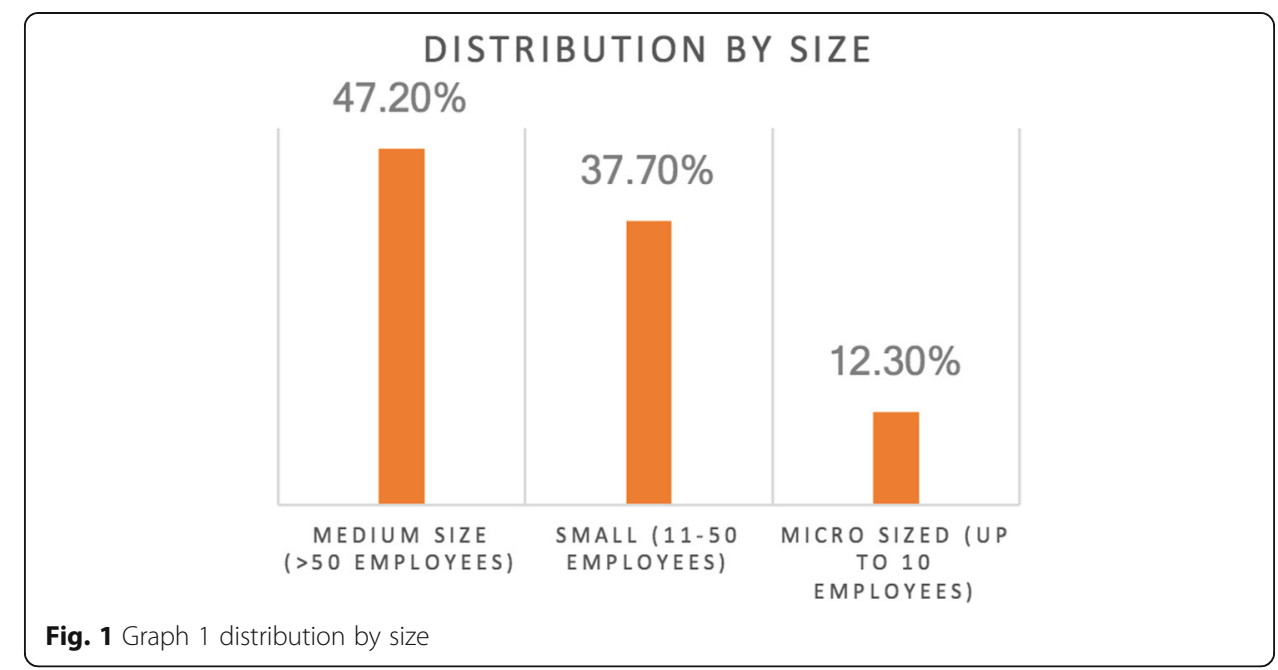

Some difficulties were identified from a small number of respondents in understanding the difference between product and service innovation. In these cases, they were asked to simply reply whether there was innovation or not in the company, without making the distinction. Furthermore, due to the limited knowledge on such topic by respondents and the relatively complicated nature of the questionnaire, in some cases, the researchers needed to make explanation of the terminology and the information needed.

\section{Research framework and methodology}

The responses were measured by using a 7-point Likert scale, ranging from 1 (strongly disagree) to 7 (strongly agree). The questions used to operationalize the concepts are

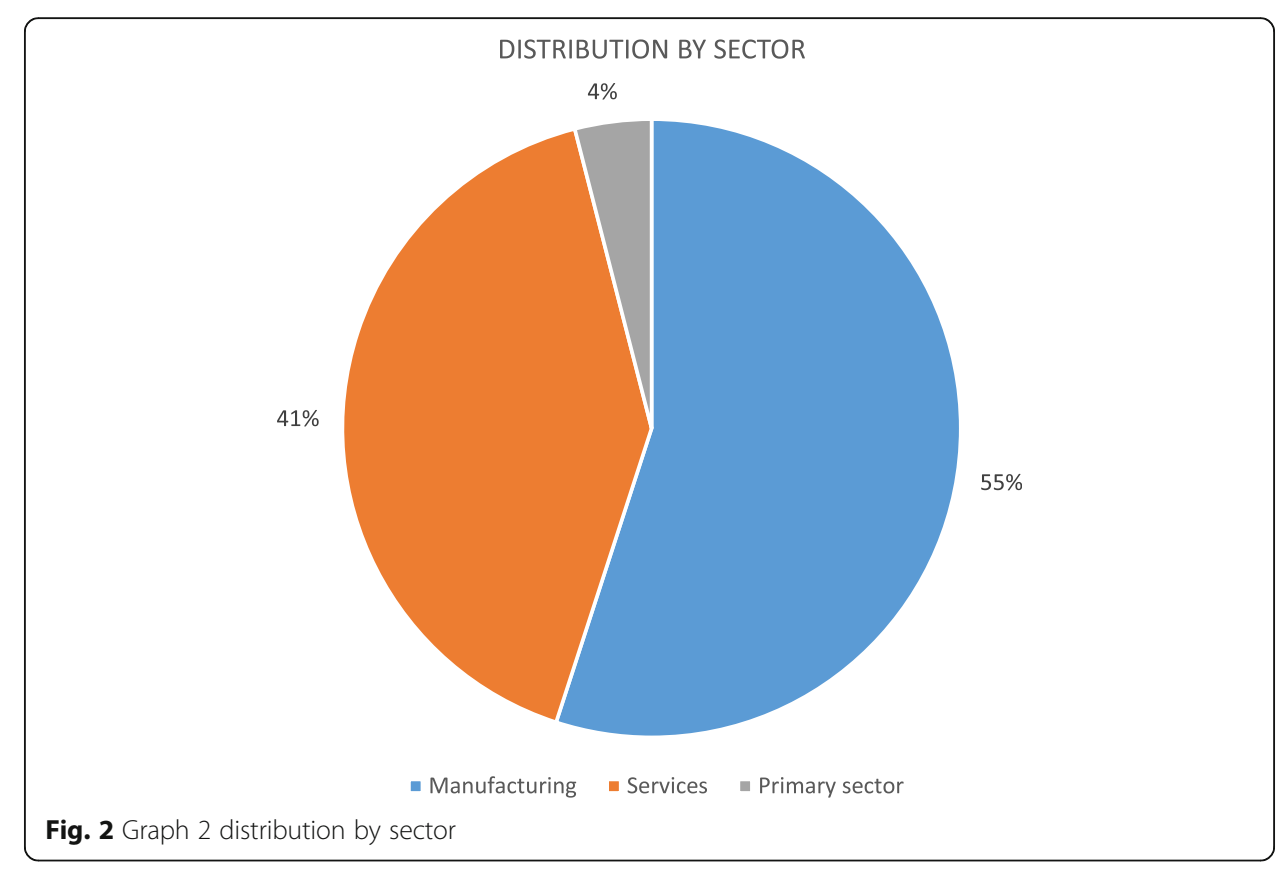




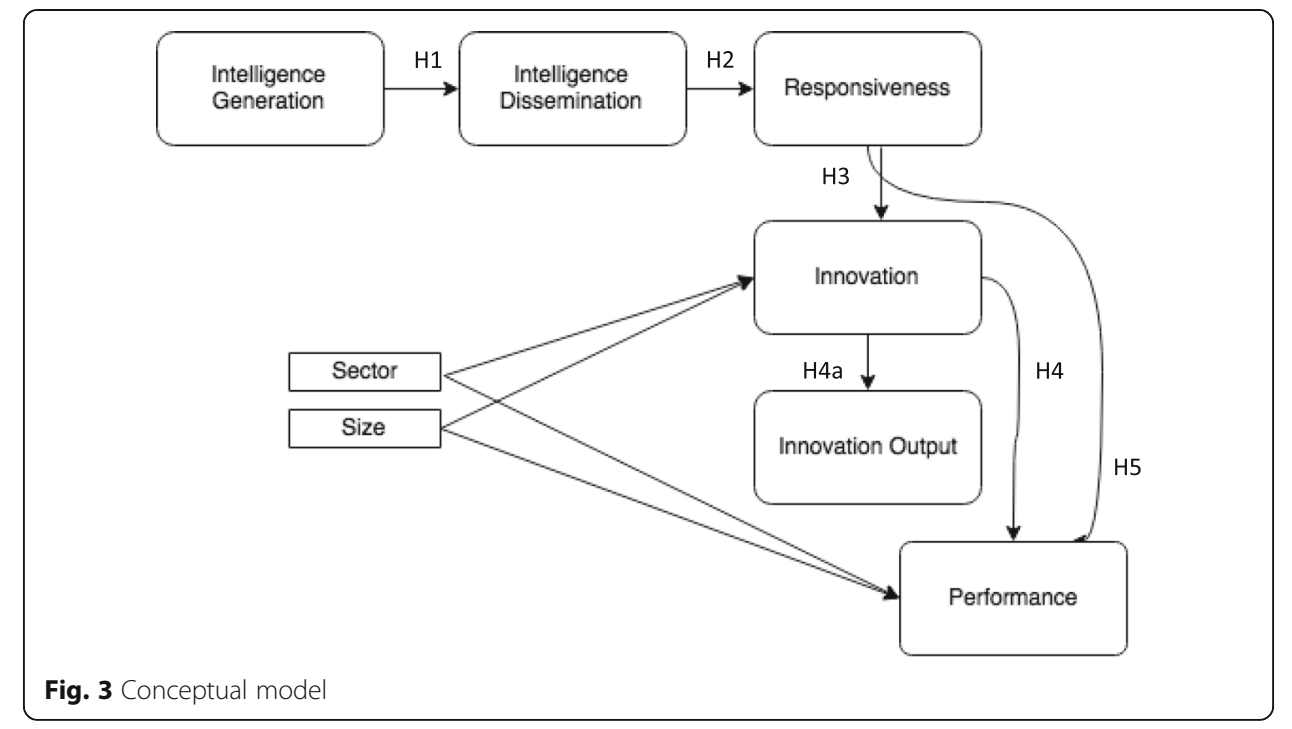

presented in Appendix. Market orientation questions were based on Kohli et al. (1993), measured by a construct of 32 questions. The construct covers three dimensions and was later tested and confirmed for reliability and validity by (2001b). After testing and construct reliability iterations, of these, six cover market intelligence generation as the first dimension, five compose the intelligence dissemination as the second dimension, and five pertain to responsiveness as the third dimension of the construct of market orientation.

The specificity of this construct is that it does not create a unique measure, but it considers the within relations and finally the overall effects on innovation, by treating market orientation as a process. The same logic is followed by Škerlavaj et al. (2010) in studying organizational learning culture and innovation. In addition, we study company performance by adding another construct. Moreover, another analyzed relationship is responsiveness, a component of the market orientation, with company performance.

We use Kohli et al. (1993) construct of market orientation comprised by intelligence generation, intelligence dissemination, and responsiveness. The first one translates and examines customer needs and forces as well as internal and environmental elements that affect their needs and preferences $(\mathrm{H} 1)$.

The second one refers to the flow of information within the organization. It takes in consideration vertical and horizontal as well as formal and informal flow of information, as essential ways of communication of the organization $(\mathrm{H} 2)$. The last one refers to the implementation as response of intelligence or information gathered, in order to achieve objectives, fulfill organizational mission, help build and sustain a competitive edge, and provide superior value for customers (H3).

The innovation construct is composed of 12 items. These items fall under 2 categories (Daft 1978; Georgantzas and Shapiro 1993) which describe technical and processes/ administrative innovations (H4, H4a). The first one defining product and service innovation (Damanpour 1991) is made up by nine variables (Škerlavaj et al. 2010). The second, administrative innovation, based on organizational processes such as rules, procedures, and structure, is measured by three variables. In addition, we measure 
innovation as an outcome, as noted by Crossan and Apaydin (2010). According to them, the innovation as a process answers the question "how", and the category pertaining innovation as an outcome answers the question "what". Moreover, innovation as an outcome includes many dimensions such as: form of innovation whether it is a product, service, process, or supposedly a business model innovation. The magnitude is another dimension including incremental and radical innovation. Another dimension according to the authors is the referent which includes firm, market, and industry innovation. Lastly, there is the type of innovation dimension including administrative and technical. We previously mention that in this model, we use this construct more as a confirmation of innovation measurement, rather than a separate construct with a specific purpose in the model. For this construct, we use three (yes or no) questions for process innovation: improvement in production, distribution, and logistics, supporting processes, and another one pertaining to product innovation.

The performance construct is measured on a Likert scale from 1 to 7 (1 poor and 7 very good) comprising on questions assessing market share, revenues, profit, cash flow, and cost reduction (Auh and Merlo 2012). Two were the issues raised for the performance construct. First, we dropped, the cost reduction question and the market share question due to low internal consistency, measured by Cronbach's alpha. Thereby, the final construct was measured with only three questions. The second issue was related to the dilemma whether we use subjective or non-subjective measures of performance. Subjective measures refer to assessing company performance with scale questions varying from 1 to 7 , or from poor to very good. On the other side, objective measures refer to questions assessing performance with indicators such as market share, return on investment, return on equity, and revenues per certain year. Kanagasabai (2008) mentions several reasons why market orientation studies opting for subjective measures of performance have more advantages. First, companies are reluctant to disclose information of real performance data. In addition, Dawes (1999) emphasizes that choosing subjective measures may be helpful when the dataset is not homogenous, and the sample of companies comes from different industries, making it easier to compare performance across industries. Moreover, going into more technicalities, another reason to opt for subjective measures is that profitability numbers not always disclose the real health of the company (Kanagasabai 2008). Considering all the theoretical implications, empirical findings and the context of the research we opted for subjective measurement of performance.

Lastly, we use two dummy variables to test for some important implications such as company size and market sector in order to measure the relationship between size and innovation as well as between size and performance. Another relationship worth exploring is the relationship between the sector and innovation, whether there is more innovation on production companies or service companies, or there is more administrative innovation in production or service companies, as well as as the relationship between the sector and the performance.

\section{Analysis}

In order to capture the complex relationships among market orientation components, innovation and performance, we use a structural equation modeling in which we include three constructs measuring three steps of market orientation: intelligence 
generation, intelligence dissemination, and reaction responsiveness. As the outside source of innovation, the other one referring to internal source such as R\&D. Firm innovativeness, product or process innovation, and other firm characteristics such as size and sector, and lastly performance. The analysis is confirmatory since we use previous theoretical background from vast literature to build constructs and associate relationships. Initially, we define all individual constructs in order to develop a measurement model for the overall study. The operationalization of the concepts follow the techniques of prior research studies as mentioned above.

\section{Results}

The construct validity is checked by convergent validity and discriminant validity. The constructs were first tested for internal consistency to check how closely related were the questions of the survey in creating a single latent (see Table 1). The intelligence generation and reaction responsiveness showed and accepted internal consistency with a Cronbach's alpha $>.70$, whether intelligence dissemination and innovativeness showed a very good internal consistency (Cronbach's alpha above .80). Construct reliability is satisfactory taking into consideration that alphas for all constructs are above .70 as shown in Table 1.

Further, we check for composite reliability (CR) of the latent variables (see Table 1). Values over .70 indicate an overall reliability of the latent variables (Hair 1998). Results show a good reliability of the constructs. In addition, we check for the overall fit of the model. The results show that the model has an overall significance, $p<0.01$, and an acceptable goodness of fit, despite being at theoretical limits. CFI (comparative fit index), CMIN/DF, root mean square error of approximation (RMSEA) indicate a good level of reliability of the model (see Table 2). The debate going over the multitude of indexes used to asses global fit of models (Škerlavaj et al. 2010; Hair et al. 2015) indicates, and research supports it (Bollen and Long 1993), that using more than one index is more convenient. In our case, supporting CFI and RMSEA, the degrees of freedom do not exceed 2 (1.748), thus, showing a good fit of the structural model to the data.

The main results are shown in Table 3 while shown in Table 4 are factors correlations. Intelligence generation proves to be a good determinant of intelligence dissemination. An increase of intelligence generation is associated with an increase of $+1.74(p<0.01)$ of intelligence dissemination, suggesting a significantly positive and strong relation between the two concepts and confirming the first hypothesis. Indeed,

Table 1 Cronbach's alpha of latent variables

\begin{tabular}{lll}
\hline & No. of items & Cronbach's alpha \\
\hline Intelligence generation & 8 & .76 \\
Intelligence dissemination & 5 & .79 \\
Reaction responsiveness & 8 & .81 \\
Innovation & 12 & .91 \\
Performance & 3 & .90 \\
Innovation output & 4 & .71 \\
\hline
\end{tabular}


Table 2 Model fit summary

\begin{tabular}{lcc}
\hline CMIN/DF $^{\mathrm{a}}$ & $\mathrm{CFI}^{\mathrm{b}}$ & RMSEA $^{\mathrm{c}}$ \\
\hline 1.748 & .767 & .087 \\
\hline${ }^{\mathrm{a} C M I N / D F}$ : discrepancy between Sigma(theta) and unrestricted S/degrees of freedom). Acceptable if $<3$ & \\
${ }^{\mathrm{b}} \mathrm{CFI}$ (comparative fit index) based on the non-centrality, indicates a good fit if its values get around 1 & \\
${ }^{\mathrm{C}} \mathrm{RMSEA}$ (root mean square error of approximation) one of the most important goodness of fit indicators. It shows a good \\
fit for values $<.8$
\end{tabular}

assigning greater importance to intelligence generation leads to better intelligence dissemination.

Following the path, intelligence dissemination shows a positive and significant relation with responsiveness. For each increase of intelligence dissemination, responsiveness increases by .628 $(p<0.01)$. The positive relationship confirms H2.

Same positive and significant relation is found between responsiveness and innovation. For each increase of responsiveness, there is a significantly positive increase of innovation, even though the relation is relatively low: 0.262 ( $p<0.01)$, confirming H3.

Innovation did not prove to be as strong determinant of performance as expected, the relationship is positive $0.125(p<0.25)$ and weak, but non-significant taking into consideration the $p$ value.

The relationship raised theoretically here as a double check and as a clear division of innovation as a process and innovation as an outcome, is expressed here through the positive and significant effect of $0.453(p<0.01)$ between the construct of innovation as a process and innovation as an output, therefore, confirming $\mathrm{H} 4 \mathrm{a}$.

The last relationship among non-moderating variables, responsiveness, and performance proved to be as expected. Responsiveness, of the market orientation construct, proved to be a good determinant of performance, an increase in responsiveness is associated with an 0.328 increase in performance. The relationship is positive, strong, and with acceptable significance level $(p<0.1)$.

Size shows to be a significant determinant of innovation and performance, but the relationship in both cases is very weak (quite 0), thus, irrelevant.

Sector shows a significant and negative relationship with innovation confirming that production companies tend to have $0.316(p<0.05)$ less innovation than service companies. The same negative relationship is also when it comes to sector-performance

Table 3 SEM factor weights

\begin{tabular}{|c|c|c|c|c|c|c|}
\hline & & & Estimate & S.E. & C.R. & P \\
\hline Intelligence dissemination & $<$ & Intelligence generation & 1.740 & .449 & 3.878 & *** \\
\hline Responsiveness & $<$ & Intelligence dissemination & .628 & .127 & 4.939 & *** \\
\hline Innovation & $<$ & Responsiveness & .262 & .100 & 2.636 & .01 \\
\hline Innovation & $<$ & Size & .001 & .000 & 1.730 & .08 \\
\hline Innovation & $<$ & Sector & -.313 & .162 & -1.934 & .05 \\
\hline Innovation output & $<$ & Innovation & .453 & .078 & 5.792 & *** \\
\hline Performance & $<$ & Innovation & .153 & .133 & 1.148 & .25 \\
\hline Performance & $<$ & Size & .001 & .001 & 1.640 & .10 \\
\hline Performance & $<$ & Sector & -.046 & .193 & -.240 & .81 \\
\hline Performance & $<$ & Responsiveness & .328 & .126 & 2.607 & .01 \\
\hline
\end{tabular}

*** indicates $p$ value $<0.01$ 
Table 4 Factors correlations

\begin{tabular}{lllllll}
\hline & 1 & 2 & 3 & 4 & 5 & 6 \\
\hline 1. Intelligence generation & 1.000 & & & & & \\
2. Intelligence dissemination & .920 & 1.000 & & & & \\
3. Responsiveness & .871 & .947 & 1.000 & & & \\
4. Innovation & .281 & .305 & .322 & 1.000 & \\
5. Performance & .331 & .360 & .380 & .271 & 1.000 \\
6. Innovation output & .243 & .264 & .279 & .865 & .234 & 1.000 \\
\hline
\end{tabular}

relationship, but in this case, the relationship is very weak and non-significant with a $p$ value of 0.81 .

Composite reliability $(\mathrm{CR})$ presumes that the used latent constructs in the model are coherent in the measurement model (Table 5). The general acceptable number is the scope of wide discussions, however, some authors suggest values more than 0.8 (Koufteros 1999), while others find values of 0.6 acceptable (Diamantopoulos and Siguaw 2000). Our latent constructs have values that are acceptable and show consistency of indicators in the measurement.

Average variance extracted (AVE) explains the average amount of variance that the latent construct can explain (Farrell and Rudd 2009), and the most recommended limit value is 0.5 (Bagozzi and Yi 1988; Hair 1998), moreover, literature also recognizes cases where 0.4 is satisfactory (Diamantopoulos and Siguaw 2000; Hair et al. 2015). Taking the lower value as a standard, taking into consideration every limit of this study and its sample size, we still have issues with two of the latent constructs, intelligence generation, and innovation output. The former one is more significant to the study as is a relevant construct to the whole model, the later one in the conceptualization of the overall model is more an artifice than a backbone element of the model.

\section{Conclusions}

The confirmation of the first and second hypothesis shows that intelligence generation, dissemination and acting on it is a process that transforms market feedback into valuable action. The overall process of market orientation happens simultaneously with organizational learning and capacity building because the evaluability of that action is proved by confirmation of hypotheses 3 and 5 . Responsiveness, as a market orientation component, proves to be a good determinant of innovation and firm performance, despite the weaker effect it has on innovation rather than performance. Recapping, intelligence generation strongly affected intelligence dissemination, and intelligence dissemination responsiveness on information gathered. In other words, it means the ability to acquaint market information from customers, competitors, and other operators and to respond on it properly by giving them innovative products and services.

Two elements in the model stayed in the conundrum of theory. The first one is organizational size. Literature puts forth a great inconsistency regarding to size and innovation and firm performance. In case of innovation, researchers argue that the source of inconsistency is variable measurement, whether it is number of employees, logarithm of number of employees, or revenue, etc. (Damanpour and Gopalakrishnan 
Table 5 Equation factor loadings and composite reliability

\begin{tabular}{|c|c|c|c|c|c|c|}
\hline Variables codes* & $\begin{array}{l}\text { Intelligence } \\
\text { generation }\end{array}$ & $\begin{array}{l}\text { Intelligence } \\
\text { dissemination }\end{array}$ & Responsiveness & Innovation & $\begin{array}{l}\text { Innovation } \\
\text { output }\end{array}$ & Performance \\
\hline$\overline{M O I G 1}$ & 1.000 & & & & & \\
\hline MOIG2 & 1.222 & & & & & \\
\hline MOIG3 & 1.644 & & & & & \\
\hline MOIG5 & 1.736 & & & & & \\
\hline MOIG8 & 1.437 & & & & & \\
\hline MOIG10 & 1.124 & & & & & \\
\hline MOID2 & & 1.000 & & & & \\
\hline MOID3 & & 1.092 & & & & \\
\hline MOID4 & & 1.042 & & & & \\
\hline MOID5 & & .468 & & & & \\
\hline MOID6 & & .870 & & & & \\
\hline MOR2 & & & 1.000 & & & \\
\hline MOR4 & & & .977 & & & \\
\hline MOR6 & & & 1.723 & & & \\
\hline MOR8 & & & .777 & & & \\
\hline MOR9 & & & 1.261 & & & \\
\hline ITI1 & & & & 1.000 & & \\
\hline IT12 & & & & 1.229 & & \\
\hline ITI3 & & & & 1.531 & & \\
\hline IT|4 & & & & 1.121 & & \\
\hline ITI5 & & & & 1.582 & & \\
\hline IT16 & & & & 1.554 & & \\
\hline ITI7 & & & & 1.486 & & \\
\hline ITI8 & & & & 1.443 & & \\
\hline ITI9 & & & & 1.592 & & \\
\hline IPI1 & & & & .663 & & \\
\hline $\mid \mathrm{PI} 2$ & & & & .266 & & \\
\hline $\mathrm{IPI}$ & & & & .625 & & \\
\hline INPGD & & & & & 1.000 & \\
\hline INPSPD & & & & & .470 & \\
\hline INPSLG & & & & & .480 & \\
\hline INPSSU & & & & & .477 & \\
\hline FFMS & & & & & & 1.000 \\
\hline FR & & & & & & 1.272 \\
\hline FFP & & & & & & 1.359 \\
\hline FCF & & & & & & 1.304 \\
\hline Composite reliability (CR) & .7582 & .7949 & .8137 & .9130 & .7070 & .8834 \\
\hline $\begin{array}{l}\text { Average variance } \\
\text { extracted (AVE) }\end{array}$ & 0.3240 & 0.4179 & 0.4171 & 0.5178 & 0.3067 & 0.6640 \\
\hline
\end{tabular}

*Refer to appendix for detailed questions of each component 
1998; Gopalakrishnan and Damanpour 1997). Nevertheless, there was no revelation as regarding to a side, whether size affects innovation and which way as our model showed very weak relationship.

We find that service providing companies are more innovative than production ones. Theoretically, innovation in manufacturing industries relies more on internal sources of innovation such as R\&D. Thereby, taking into consideration the lack of $R \& D$ structures and departments in Albanian organizations, let alone R\&D investments in capacity creation, the implication seems reasonable. More contextually, the business model in Albanian firms for a long time has been copycatting, meaning importing an idea and implementing it quickly in the market. This model is not consistent with time, capacity, analysis, and financial requirements of manufacturing industries.

Limitations: despite the fact that the responses were collected during a face-toface interview, there were difficulties from the respondents to understand the difference between product and service innovation. Those who did not understand the difference were asked to reply whether there was innovation or not in the company. Furthermore, the limited knowledge on such topic by the respondents and the relatively complicated nature of the questionnaire made it difficult to have a common sense in the responses.

Another important limitation is related to the sample size. The representativeness of the sample is related to the initial pool of 870 companies identified as innovative from the Albanian Institute of Statistics, thus, the generalization of these findings does not apply for the Albanian companies in general but only for those which are deemed to have innovative features.

Implications for future research: at the best of our knowledge, this is the first to shed light on the market orientation, innovation, and performance of Albanian companies. Yet, more research is needed on the organization learning and absorptive capacities of the Albanian companies, in order to have a full understanding of the determinants of innovation. Furthermore, we operationalized the performance by using subjective measures. Other researchers might use objective performance measures in order to relate market orientation and innovation with economical and financial indicators.

\section{Appendix}

Intelligence generation

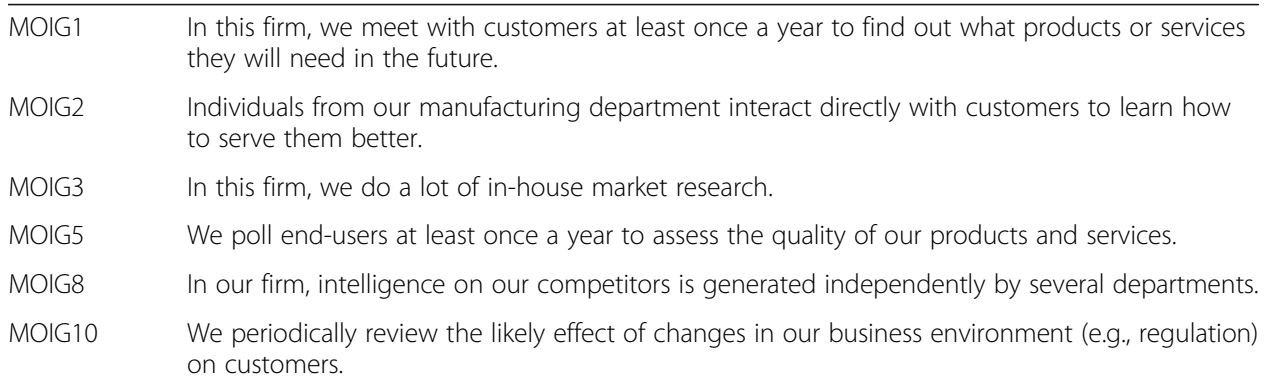




\section{Intelligence dissemination}

\begin{tabular}{ll}
\hline MOID2 & $\begin{array}{l}\text { We have interdepartmental meetings at least once a quarter to discuss market trends and } \\
\text { developments. }\end{array}$ \\
MOID3 & $\begin{array}{l}\text { Marketing personnel in our firm spend time discussing customers' future needs with other } \\
\text { functional departments. }\end{array}$ \\
MOID4 & Our firm periodically circulates documents (e.g., reports, newsletters) that provide information \\
on our customers. & \\
WOID5 & When something important happens to a major customer of market, the whole firm knows \\
MOID6 & Data on customer satisfaction are disseminated at all levels in this firm on a regular basis.
\end{tabular}

\section{Responsiveness}

\begin{tabular}{ll}
\hline MOR2 & Principles of market segmentation drive new product development efforts in this firm. \\
MOR4 & We periodically review our product development efforts to ensure that they are in line with \\
what customers want. & Several departments get together periodically to plan a response to changes taking place in \\
our business environment. \\
MOR8
\end{tabular}

\section{Product and service (technical) innovation}

\begin{tabular}{ll}
\hline ITI1 & In new product and service introduction, our company is often first-to-market. \\
ITI2 & Our new products and services are often perceived as very novel by customers. \\
ITI3 & New products and services in our company often take us up against new competitors. \\
ITI4 & $\begin{array}{l}\text { In comparison with competitors, our company has introduced more innovative products and services } \\
\text { during the past } 3 \text { years. }\end{array}$ \\
ITI5 & We constantly emphasize development of particular products and services. \\
ITI6 & We manage to cope with market demands and develop new products and services quickly. \\
ITI7 & We continuously modify design of our products and services and rapidly enter new markets. \\
ITI8 & Our firm manages to deliver special products/services flexibly according to customers' orders. \\
ITI9 & We continuously improve old products and services and raise quality of new products.
\end{tabular}

(Škerlavaj et al. 2010)-second dimension: process (administrative/marketing) innovations

IPI1 Development of new channels for products and services offered by our corporation is an on-going process.

IPI2 We deal with customers' suggestions or complaints urgently and with utmost care.

IPI3 In marketing innovations (entering new markets, new pricing methods, new distribution methods, etc.) our company is better than competitors. 
Product (INPGD) and process innovation (as an output)

\begin{tabular}{ll}
\hline INPGD & $\begin{array}{l}\text { Product innovations: new or significantly improved goods or services (exclude the simple resale } \\
\text { of new goods and changes of the solely aesthetic nature) }\end{array}$ \\
INPSD & New or significantly improved methods of manufacturing or producing goods or services \\
INPSLG & $\begin{array}{l}\text { New or significantly improved logistics, delivery, or distribution methods for your inputs, goods, } \\
\text { or services }\end{array}$ \\
INPSSU & $\begin{array}{l}\text { New or significantly improved supporting activities for your processes, such as maintenance } \\
\text { systems or operations for purchasing, accounting, or computing }\end{array}$
\end{tabular}

Business performance according to (Auh and Merlo 2012)

\begin{tabular}{ll}
\hline FMS & Market share \\
FR & Revenues \\
FP & Profit \\
FCF & Cash flow \\
\hline
\end{tabular}

\section{Authors' contributions}

RP conceived the study, carried out the theoretical study related to fundamental concepts, definitions, construct building, participated in the model alignment, in its design, and coordination, and helped to draft the manuscript. GA carried out the critical reading and statistical aligning of the model. GA participated in the design of the study and performed the statistical analysis. GA carried out the SEM analysis and its results. Both authors read and approved the final manuscript.

\section{Competing interests}

The authors declare that they have no competing interests.

\section{Publisher's Note}

Springer Nature remains neutral with regard to jurisdictional claims in published maps and institutional affiliations.

Received: 17 December 2016 Accepted: 10 March 2017

Published online: 24 March 2017

\section{References}

Abernathy, W., \& Utterback, J. (1978). Patterns of industrial innovation. Technology Review, 80(7), 40-47. Atuahene-Gima, K. (1996). Market orientation and innovation. Journal of Business Research, 35(2), 93-176.

Auh, S., \& Merlo, O. (2012). The power of marketing within the firm: its contribution to business performance and the effect of power asymmetry. Industrial Marketing Management, 41(5), 861-873.

Bagozzi, R., \& Yi, Y. (1988). On the evaluation of structural equation models. Journal of the Academy of Marketing Science, $16,74$.

Baker, W. E., \& Sinkula, J. M. (1999). Learning orientation, market orientation, and innovation: integrating and extending models of organizational performance. Journal of Market-Focused Management, 4(4), 295-308.

Boekema, F., Morgan, K., Bakkers, S., \& Rutten, R. (2000). Knowledge, innovation and economic growth. Cheltenham: Edward Elgar Publishing.

Bollen, K. A., \& Long, J. S. (1993). Testing structural equation models. California: Sage Publications.

Calantone, R. J., Cavusgil, S. T. T., \& Zhao, Y. (2002). Learning orientation, firm innovation capability, and firm performance. Industrial Marketing Management, 31(6), 515-524.

Cameron, G. (1996) Innovation and economic growth. CEPDP, 277. Centre for Economic Performance, London School of Economics and Political Science, London, UK. ISBN 0753003007.

Capello, R., \& Lenzi, C. (2014). How firms can get ideas from users for sustainable business innovation. Journal of Regional Science, 54(2), 186-214.

Cohen, W. M., \& Levinthal, D. A. (1990). Absorptive capacity: a new perspective on learning and innovation. Administrative Science Quarterly, 35(1), 128-152. http://doi.org/10.2307/2393553.

Crossan, M. M., \& Apaydin, M. (2010). A multi-dimensional framework of organizational innovation: A systematic review of the literature. Journal of Management Studies, 47(6), 1154-1191.

Daft, R. L. (1978a). A dual-core model of organizational innovation. Academy of Management Journal, 21(2), 193-210. http://doi.org/10.2307/255754.

Damanpour, F. (1991). Organizational innovation: a meta-analysis of effects of determinants and moderators. The Academy of Management Journal, 34(3), 555-590. http://doi.org/ 10.2307/256406. 
Damanpour, F., \& Gopalakrishnan, S. (1998). Theories of organizational structure and innovation adoption: the role of environmental change. Journal of Engineering and Technology Management, 15(1), 1-24.

Dawes, J. (1999). The relationship between subjective and objective company performance measures in market orientation research: further empirical evidence. Marketing Bulletin-Department of Marketing Massey.

De Luca, L. M., \& Atuahene-Gima, K. (2007). Market knowledge dimensions and cross-functional collaboration: examining the different routes to product innovation performance. Journal of the American Marketing Association, $71(1), 95-112$

Deng, S., \& Dart, J. (1994). Measuring market orientation: a multifactor, multiitem approach. Journal of Marketing Management, 10(8), 725-742.

Deshpande, R. J., \& Webster, F. J. (1989). Organizational culture and marketing: defining the research agenda. The Journal of Marketing, 53(1), 3-15.

Deshpande, R., Farley, J., \& Jr, F. W. (1993). Corporate culture, customer orientation, and innovativeness in Japanese firms: a quadrad analysis. The Journal of Marketing, 57(1), 23-37.

Diamantopoulos, A., \& Siguaw, J. (2000). Introducing LISREL: a guide for the uninitiated. Introducing statistical methods series.

Ettlie, J. E., Bridges, W. P., \& Keefe, R. D. O. (1984). Organization strategy and structural differences for radical versus incremental innovation. Management Science, 30(6), 682-695.

Farrell, A., \& Rudd, J. (2009). Factor analysis and discriminant validity: a brief review of some practical issues.

Frösén, J., Luoma, J., Jaakkola, M., Tel, U. K., Tikkanen, H., Aspara, J., ... Laukkanen, M. (2016). What counts vs. what can be counted: the complex interplay of market orientation and marketing performance measurement in organizational configurations. Journal of Marketing, 80(3), 1-60.

Garcia, R., \& Calantone, R. (2002). A critical look at technological innovation typology and innovativeness: a literature review. The Journal of Product Innovation Management, 19(2), 110-132.

Gatignon, H., \& Xuereb, J. (1997). Strategic orientation of the firm and new product performance. Journal of Marketing Research

Gatignon, H., Tushman, M., \& Smith, W. (2002). A structural approach to assessing innovation: Construct development of innovation locus, type, and characteristics. Management.

Georgantzas, N. C., \& Shapiro, H. J. (1993). Viable theoretical forms of synchronous production innovation. Journal of Operations Management, 11(2), 161-183.

Gopalakrishnan, S., \& Damanpour, F. (1997). A review of innovation research in economics, sociology and technology management. Omega, 25(1), 15-28.

Greenley, G. E. (1995). Market orientation and company performance: empirical evidence from UK companies. British Journal of Management, 6(1), 1-13.

Gunday, G., Ulusoy, G., Kilic, K., \& Alpkan, L. (2011). Effects of innovation on firm performance. International Journal of Production Economics, 133(2), 662-676.

Hair, J. F. (1998). Multivariate data analysis. Prentice Hall.

Hair, J. F., Black, W. C., Babin, B. J., \& Anderson, R. E. (2015). Multivariate data analysis (seventh). Pearson.

Han, J. K., Kim, N., \& Srivastava, R. K. (1998). Orientation performance : organizational is innovation a missing link? Journal of Marketing, 62(4), 30-45.

Hashi, I., \& Krasniqi, B. (2011). Entrepreneurship and SME growth: evidence from advanced and laggard transition economies. International Journal of Entrepreneurial.

Homburg, C., \& Pflesser, C. (2000). A multiple-layer model of market-oriented organizational culture: measurement issues and performance outcomes. Journal of Marketing Research, 37(4), 449-462.

Hunt, S. D., \& Lambe, C. J. (2000). Marketing's contribution to business strategy: market orientation, relationship marketing and resource-advantage theory. International Journal of Management Reviews, 2(1), 17-43. http://doi.org/ 10.1111/1468-2370.00029.

Hurley, R., \& Hult, G. (1998). Innovation, market orientation, and organizational learning: an integration and empirical examination. The Journal of Marketing, 62, 42-54.

Jaworski, B.J. \& Kohli, A.K. (1993a). Market orientation: antecedents and consequences. Journal of Marketing, July 1993; 57.

Kanagasabai, K. (2008). Market orientation and company performance: a study of selected Japanese and Sri Lankan companies, (1990).

Keskin, H. (2006). Market orientation, learning orientation, and innovation capabilities in SMEs: an extended model. European Journal of Innovation Management, 4(1), 20-31.

Kim, W. C., \& Mauborgne, R. (2005). Blue ocean strategy: from theory to practice. California Management Review, 47(3), 105-121. http://doi.org/10.2307/41166308.

Kirca, A., Jayachandran, S., \& Bearden, W. (2005). Market orientation: a meta-analytic review and assessment of its antecedents and impact on performance. Journal of Marketing, 69(2), 24-41.

Kline, S. S. J., \& Rosenberg, N. (1986). An overview of innovation. European Journal of Innovation Management, 38, 275-305. http://doi.org/10.1108/14601069810368485.

Koellinger, P. (2008). The relationship between technology, innovation, and firm performance-empirical evidence from e-business in Europe. Research Policy, 37(8), 1317-1328.

Kohli, K., Jaworski, B. J., \& Kumar, A. (1993). MARKOR: Measure of market orientation. Journal of Marketing Research, 30(4), 467-478. http://doi.org/10.2307/3172691.

Koufteros, X. (1999). Testing a model of pull production: a paradigm for manufacturing research using structural equation modeling. Journal of Operations Management, 17, 467-488.

Kumar, K., Subramanian, R., \& Yauger, C. (1998). Examining the market orientation-performance relationship: a contextspecific study. Journal of Management, 24(2), 201-233. http://doi.org/10.1177/014920639802400204.

Lado, N., \& Maydeu-Olivares, A. (2001). Exploring the link between market orientation and innovation in the European and US insurance markets. International Marketing Review, 18(2), 130-144.

Lado, N., Maydeu-Olivares, A., \& Rivera, J. (1998). Measuring market orientation in several populations: a structural equations model. European Journal of Marketing, 32(1/2), 23-39. http://doi.org/10.1108/03090569810197408. 
Léger, A., \& Swaminathan, S. (2006). Innovation theories: relevance and implications for developing countries. Berlin: German institute for economic research. DIW.

Lewrick, M. (2009). Introduction of an evaluation tool to predict the probability of success of companies: the innovativeness, capabilities and potential model (ICP). Journal of Technology Management and Innovation.

Lewrick, M., Omar, M., \& Williams, R. L. (2011). Market orientation and innovators' success: an exploration of the influence of customer and competitor orientation. Journal of Technology Management and Innovation, 6(3), 48-62.

Lukas, B., \& Ferrell, O. (2000). The effect of market orientation on product innovation. Journal of the Academy of Marketing Science, 28(2), 239-247.

Lundvall, B. (1985). Product innovation and user-producer interaction. Industrial Development Research, 31, 6.

Morgan, N., \& Vorhies, D. (2009). Market orientation, marketing capabilities, and firm performance. Strategic Management, 30(8), 909-920.

Narver, J. C. J., \& Slater, S. S. F. (1990). The effect of market orientation on business profitability. The Journal of Marketing, 54(4), 20-35.

Narver, J., Slater, S., \& MacLachlan, D. (2004). Responsive and proactive market orientation and new product success. Journal of Product.

Omri, W. (2015). Innovative behavior and venture performance of SMEs: the moderating effect of environmental dynamism. European Journal of Innovation Management, 18(2), 195-217.

Raj, R., \& Srivastava, K. B. L. (2016). Mediating role of organizational learning on the relationship between market orientation and innovativeness. The Learning Organization, 23(5), 370-384.

Rivera Camino, J. (1995). The market orientation: competitive organizational strategy. Universidad Carlos III de Madrid. Departamento de Economía de la Empresa.

Rosenberg, N. (2004). Innovation and economic growth by Nathan Rosenberg Professor of Economics (Emeritus). Stanford University.

Rosenbusch, N., Brinckmann, J., \& Bausch, A. (2011). Is innovation always beneficial? A meta-analysis of the relationship between innovation and performance in SMEs. Journal of Business Venturing, 26(4), 441-457.

Schumpeter, J. (1934). The theory of economic development: an inquiry into profits, capital, credit, interest, and the business cycle.

Škerlavaj, M., Song, J. H., \& Lee, Y. (2010). Organizational learning culture, innovative culture and innovations in South Korean firms. Expert Systems with Applications, 37(9), 6390-6403.

Sorensen, E. (2005). On market orientation: management, (November).

Tidd, J., Bessant, J., \& Pavitt, K. (2005). Managing innovation-integrating technological. Wiley: Market and Organizational Change. http://doi.org/10.1086/421629.

Utterback, J. M. (1996). Mastering the dynamics of innovation: how companies can seize opportunities in the face of technological change. Long Range Planning, 6(29), 908-909.

Vázquez, R., Santos, M. L., \& Álvarez, L. I. (2001). Market orientation, innovation and competitive strategies in industrial. Journal of Strategic Marketing, 9(1), 69-90. http://doi.org/10.1080/09652540010011493.

Vincent, L. H., Bharadwaj, S. G., \& Challagalla, G. N. (2004). Does innovation mediate firm performance?: a meta-analysis of determinants and consequences of organizational innovation. Georgia Institute of Technology.

Zhou, K., Yim, C., \& Tse, D. (2005). The effects of strategic orientations on technology-and market-based breakthrough innovations. Journal of Marketing, 69(2), 42-60.

\section{Submit your manuscript to a SpringerOpen ${ }^{\circ}$} journal and benefit from:

- Convenient online submission

- Rigorous peer review

- Immediate publication on acceptance

Open access: articles freely available online

- High visibility within the field

- Retaining the copyright to your article

Submit your next manuscript at $>$ springeropen.com 